\title{
Effect of bovine seminal plasma on neutrophil phagocytosis of bull spermatozoa
}

\author{
P. J. Strzemienski \\ Laboratory of Microbiology and Immunology, Department of Clinical Studies, \\ University of Pennsylvania, School of Veterinary Medicine, New Bolton Center, Kennett Square, \\ Pennsylvania 19348, USA
}

\begin{abstract}
Summary. Seminal plasma was obtained from bulls of known fertility and was assessed for its effect on serum-induced phagocytosis of bull spermatozoa. A non-dialysable component was found to inhibit neutrophil phagocytic uptake of spermatozoa. The component was not destroyed by heating $\left(56^{\circ} \mathrm{C}\right.$ for $30 \mathrm{~min}$ ) or removed by ether. Use of a bactericidal assay confirmed the inhibition and suggested that inhibition does not permanently impair neutrophil function.

Immunoperoxidase staining demonstrated the presence of bovine $\operatorname{IgM}, \operatorname{IgG}_{1}$ and $\mathrm{IgG}_{2}$ on spermatozoa incubated in serum. Affinity of spermatozoa for the immunoglobulins was reduced when seminal plasma was added to the serum.

These results suggest that bull seminal plasma can regulate phagocytic ingestion of spermatozoa. While the mechanism of this regulation remains obscure, it may be important in providing protection to spermatozoa immediately after ejaculation.
\end{abstract}

Keywords: bull; seminal plasma; spermatozoa; neutrophil; phagocytosis

\section{Introduction}

Since early observtions documenting the removal of spermatozoa by the female genital tract (Sobotta, 1895, as cited by Austin, 1957), studies have further characterized events leading to elimination of those spermatozoa not successful at fertilization. Sperm removal has been shown to occur by degradation, uterine evacuation (Blandau \& Odor, 1949; Austin, 1957) and phagocytic ingestion (Austin, 1957; Howe \& Black, 1963; Bedford, 1965; Marcus, 1966). However, these events, including the requirements needed for the phagocytic ingestion of spermatozoa, are not well defined (Olive et al., 1987).

Contamination of semen by microorganisms is common (Fowler \& Mariano, 1984; Busolo et al., 1984), and it is possible that spermatozoa may carry microflora into the female genital tract (Friberg \& Fullan, 1983; Busolo et al., 1984). The female genital tract must restrict microflora growth while ensuring optimal conditions for sperm survival. Control of uterine bacterial growth by immunoglobulins can occur either directly by blocking attachment sites and preventing bacteria from binding to the epithelium, or indirectly by agglutination and opsonization of bacteria for phagocytic ingestion (Parr \& Parr, 1985). Similar mechanisms can also be proposed for the removal of spermatozoa. It appears that the polymorphonuclear leucocyte plays a major role in both bacterial and sperm removal (Hawk et al., 1960; Menge et al., 1962; Parr et al., 1967). Obviously, factors modulating neutrophil response would influence this removal. Complement, which can facilitate opsonization of bacteria, also restricts sperm survival in the female reproductive tract (Bedford \& Witkin, 1983). The importance of the leucocyte in this restriction is debatable (Bedford \& Witkin, 1983). 
The immunosuppressive effects of seminal plasma factors are well known (Matousek, 1985; Alexander \& Anderson, 1987), and may aid sperm survival in the female genital tract. While having a possible advantage to sperm survival, seminal plasma factors may also impair microflora control. Information concerning the effects of seminal plasma on phagocyte function is limited (Alexander \& Anderson, 1987).

In the present study, the modulation of neutrophil phagocytic ingestion of spermatozoa by bovine seminal plasma was assessed and verified with an antibacterial assay.

\section{Materials and Methods}

Seminal plasma and sperm preparation. Semen was collected by an artificial vagina from fertile bulls undergoing progeny testing (Atlantic Breeder's Cooperative, Lancaster, PA, USA). Upon collection, semen was immediately assessed for concentration, motility and morphology. Citrated blood $(10 \mathrm{ml}$ of $3.8 \%$ sodium citrate in $50 \mathrm{ml}$ blood) and blood for serum were obtained from the jugular vein.

On reaching the laboratory $(\approx 1 \mathrm{~h})$, the semen was centrifuged for $20 \mathrm{~min}$ at $1000 \mathrm{~g}$. Seminal plasma was recentrifuged at $10000 \mathrm{~g}$ for $30 \mathrm{~min}$ at $4^{\circ} \mathrm{C}$. The supernatant was filter-sterilized $(0.22 \mu \mathrm{m})$ and kept at $4^{\circ} \mathrm{C}$ until assay or immediately frozen at $-20^{\circ} \mathrm{C}$. Sperm cells were washed by centrifugation $(20 \mathrm{~min}$ at $1000 \mathrm{~g}$ ) three times with Dulbecco's phosphate-buffered saline (PBS; GIBCO, Grand Island, NY, USA) modified by the addition of 0.01 M-4(2-hydroxy-ethyl)-1-piperazine-ethane-sulphonic acid (Sigma Chemical Co., St Louis, MO, USA; pH 7-4). After the final wash, spermatozoa were resuspended in an assay buffer of PBS containing $0.22 \%$ dextrose (pH 7.4 ; PBSA). Sperm concentration was determined with a haemocytometer by counting the heads. Clotted blood taken for serum was kept at $4^{\circ} \mathrm{C}$ for $\approx 2 \mathrm{~h}$. Serum was removed after centrifugation for $15 \mathrm{~min}$ at $4^{\circ} \mathrm{C}(1500 \mathrm{~g})$. All manipulations described were done using sterile-capped polypropylene tubes. All buffers were made from double-distilled, pyrogenfree water and were filter-sterilized $(0.22 \mu \mathrm{m})$.

Neutrophil isolation. Citrated whole blood $(12 \mathrm{ml})$ was added to $30 \mathrm{ml}$ sterile double-distilled, pyrogen-free water for $45 \mathrm{sec}$. Immediately, $4 \mathrm{ml}$ of a 10-times concentrate of PBS were added to restore tonicity. After centrifugation ( $200 \mathrm{~g}$ for $10 \mathrm{~min}$ ), the pellet was resuspended in $16 \mathrm{ml}$ PBS, and $8 \mathrm{ml}$ were layered over $3 \mathrm{ml}$ Histopaque (Sigma Chemical Co.) and were centrifuged ( $30 \mathrm{~min}$ at $200 \mathrm{~g}$ ). The pellet was resuspended in PBS and was washed once ( $200 \mathrm{~g}$ for $10 \mathrm{~min}$ ). Neutrophils were suspended in PBSA and were counted with a haemocytometer. Using Trypan blue exclusion, cell preparations with $>96 \%$ live neutrophils were used. The cell suspension was kept at $4^{\circ} \mathrm{C}$ before use.

Bacterial preparation and bactericidal assay. Staphylococcus aureus (ATCC 27217) was used in a bactericidal assay (Strzemienski et al., 1987) modified to allow incorporation of seminal plasma. The neutrophil preparation (100 $\mu$; diluted to $3 \times 10^{6} / \mathrm{ml}$ ) and opsonin $(100 \mu \mathrm{l})$ was added to duplicate assay tubes. After the addition of seminal plasma, PBSA was added for final volume of $1 \mathrm{ml}$. Assay tubes were sampled at the start $(0$ time) and after $2 \mathrm{~h}$ of incubation with constant rotation. Results were tabulated as percentage dead and were converted to common logarithms before statistical analysis (Hoffman \& Bullock, 1973). Values were reported as the geometric means with $95 \%$ confidence levels (Sokal \& Rohlf, 1981).

Sperm phagocytic assay. Spermatozoa and neutrophils were diluted to $3 \times 10^{6} \mathrm{cells} / \mathrm{ml}$ in PBSA. Both cell suspensions were added in $100 \mu \mathrm{l}$ volumes to duplicate $12 \times 75$ tubes. Seminal plasma and/or serum $(100 \mu \mathrm{l})$ was then added. PBSA was added for a final volume of $1 \mathrm{ml}$. Spermatozoa and neutrophils suspended in PBSA alone were used as an additional control. Tubes were rotated $(17 \mathrm{rev} . / \mathrm{min})$ at $37^{\circ} \mathrm{C}$. Phagocytosis was stopped by adding $1 \mathrm{ml} \mathrm{cold}\left(4^{\circ} \mathrm{C}\right) 4 \%$ paraformaldehyde in phosphate-buffered saline $(\mathrm{pH} 7 \cdot 4)$. After fixation for $1-2 \mathrm{~h}\left(4^{\circ} \mathrm{C}\right), 0.2 \mathrm{ml}$ from each tube was used to prepare a cytocentrifuge preparation $(190 \mathrm{~g}$ for $10 \mathrm{~min}$; Shandon Southern Instruments, Inc., Sewickley, PA, USA). Slides were stained with Harris' haematoxylin and erythrosin $\mathbf{B}$.

Using an oil-immersion lens, at least 100 neutrophils were scored for phagocytosis. A neutrophil was considered to be exhibiting phagocytosis when the cytoplasm appeared to be elongated over the sperm cell surface. Results were expressed as the percentage of neutrophils exhibiting phagocytosis. The values were converted to common logarithms before statistical analysis.

Immunoperoxidase detection of immunoglobulins. Bovine $\mathrm{IgM}, \mathrm{IgG}_{1}$, and $\mathrm{IgG}_{2}$ were localized on sperm cells indirectly, using a peroxidase conjugated antibody (Bergroth et al., 1980). Working dilutions of primary and secondary antisera were established by incubating cytocentrifuge preparations of washed spermatozoa in $10 \%$ autologous serum diluted in Tween buffer $(0.05 \mathrm{M}$-Tris ( $\mathrm{pH} 7.6)$ containing $0.05 \%$ Tween 20 and $0.9 \% \mathrm{NaCl}$ ) for $1 \mathrm{~h}$ at $37^{\circ} \mathrm{C}$ in a humidified chamber. After 3 washings in Tween buffer, primary antisera (subclass-specific anti-bovine IgG $_{1}$ and $\mathrm{IgG}_{2}$, or Fc-specific IgM (Nordic Immunological Labs, Capistrano Beach, CA, USA) were incubated with spermatozoa for $1 \mathrm{~h}$ at $37^{\circ} \mathrm{C}$. After 3 washes with Tween buffer, peroxidase-conjugated, affinity-purified goat antirabbit IgG (Kirkegaard and Perry Laboratories, Inc., Gaithersburg, MD, USA) was incubated with the sperm cells at $4^{\circ} \mathrm{C}$ overnight in a humidified chamber. Both primary and secondary antisera were diluted in Tween buffer containing $1.0 \%$ normal goat serum (Miles Laboratories, Elkhart, IN, USA). After 3 washings in Tween buffer and one wash in 
$0.05 \mathrm{M}-\mathrm{Tris}-\mathrm{HCl}(\mathrm{pH} 7.6)$, slides were placed in a substrate solution (prepared just before use by mixing equal volumes of $0.02 \%(\mathrm{v} / \mathrm{v})$ hydrogen peroxide in distilled water with $0.1 \%$ diaminobenzidine tetrahydrochloride (Sigma) made in $0.1 \mathrm{M}$-Tris- $\mathrm{HCl}$ at $\mathrm{pH} 7.2$ ) for $10 \mathrm{~min}$ at room temperature. A tap-water wash stopped the reaction. Controls consisted of spermatozoa not incubated with serum and omission of the primary and/or conjugated antiserum.

Experiment $I$. In this experiment, filter-sterilized seminal plasma was observed for antibacterial and antiphagocytic properties. Blood, for the harvesting of neutrophils and serum, and semen were obtained from 5 bulls. The bactericidal assay was run simultaneously with the sperm phagocytosis assay. Seminal plasma $(10 \%)$ was added to heated $\left(56^{\circ} \mathrm{C}\right.$ for $30 \mathrm{~min}$ ) and to fresh serum, and was added alone to assay tubes. Buffer and serum with and without heat inactivation served as controls. In the bactericidal assay, addition of bacteria to buffer not containing neutrophils served as the bacterial control. The sperm phagocytosis assay was stopped after 30 min with fixative. Both the bactericidal and sperm phagocytosis assay were analysed as a two-way analysis of variance having treatment and animal as factors (Sokal \& Rohlf, 1981). Differences between treatments $(P<0.05)$ were determined by Least Significant Difference (Sokal \& Rohlf, 1981).

Experiment 2. This experiment was designed to establish a dose-response of seminal plasma on neutrophil phagocytosis of spermatozoa. Whole ejaculates were obtained from 5 bulls. After the final centrifugation, seminal plasma was dialysed $\left(M_{\mathrm{r}} 12000\right.$ cut off $)$ against PBS for $48 \mathrm{~h}$ at $4^{\circ} \mathrm{C}$ and filter-sterilized $(0.22 \mu \mathrm{m})$. Activity from tritiated PGF-2a (3000 c.p.m.; DuPont Co., Boston, MA, USA) added to two samples of seminal plasma was reduced to background after dialysis for $24 \mathrm{~h}$. Dialysed seminal plasma was added to duplicate assay tubes to give final concentrations of 50,25 and $10 \%$, respectively. The assay was stopped after $10 \mathrm{~min}$ with fixative. Neutrophils, fresh serum and spermatozoa were used from one bull. Neutrophils and spermatozoa in buffer, in serum alone, and in seminal plasma alone served as controls. Data were analysed as a two-way analysis of variance with treatment and animal as factors. Differences between treatments $(P<0.01)$ were determined by Least Significant Differences. To study the influence of seminal plasma on sperm immunoglobulin localization, cytocentrifuge preparations were made from each assay tube of Exp. 2. After 3 washes with Tween-Tris buffer, preparations were incubated with primary and secondary antisera using the controls already described.

Experiment 3. Pooled seminal plasma was treated and assessed with the sperm phagocytosis and/or bactericidal assay. Whole ejaculates were collected from 13 bulls and combined into two pools $(n=5$ and $n=8)$. An aliquant of each pool was filter-sterilized after the last centrifugation and kept at $4^{\circ} \mathrm{C}$ until assay. A second aliquant was dialysed against PBS ( $4^{\circ} \mathrm{C}$ for $48 \mathrm{~h}$ ) and half was heated $\left(56^{\circ} \mathrm{C}\right.$ for $\left.30 \mathrm{~min}\right)$ before use. A third aliquant was ether-extracted by the method of Hurn \& Chantler (1980) before dialysis and subsequent filter-sterilization. Seminal plasma was assayed at a $50 \%$ concentration for the bactericidal and the sperm phagocytosis assay. All 4 treatments were tested in the sperm phagocytosis assay, while only the dialysed and ether-extracted dialysed pools were tested in the bactericidal assay. Neutrophils and fresh serum were obtained from a parous cow. For both assays, seminal plasma was tested with and without the addition of fresh serum. Data were analysed as a two-way analysis of variance having 2 levels of replication/pool. Differences between treatments $(P<0.01)$ were determined by Least Significant Difference.

Experiment 4. To determine whether seminal plasma had a lasting effect on neutrophil function, neutrophils isolated from the same cow that was used in Exp. 3 were incubated $(17 \mathrm{rev} . / \mathrm{min})$ in dialysed seminal plasma $(50 \%)$ from each of 2 bulls for $2 \mathrm{~h}$ at $37^{\circ} \mathrm{C}$. Controls consisted of neutrophils kept at $4^{\circ} \mathrm{C}$ in PBS and of neutrophils rotated for $2 \mathrm{~h}$ at $37^{\circ} \mathrm{C}$ in PBS. After 2 washes the PBS $(200 \mathrm{~g}$ for $10 \mathrm{~min})$, neutrophils were resuspended in PBSA and used in the bactericidal assay. Bactericidal activity of neutrophils was tested with and without the addition of fresh serum. Neutrophil viability was assessed before and after seminal plasma incubation using Trypan blue exclusion. Neutrophil bactericidal activity was analysed as a two-way analysis of variance with three levels of treatment and two levels of replication.

\section{Results}

\section{Experiment 1}

After $30 \mathrm{~min}$ of incubation, phagocytic activity due to heat-treated serum was reduced $(P<0.05)$ by the addition of $10 \%$ seminal plasma (Table 1$)$. Increased phagocytic activity $(P<0.05)$ was also observed with fresh serum, but this increase could not be reduced $(P>0.05)$ with the addition of seminal plasma. Phagocytic activity of buffer control tubes was similar $(P>0.05)$ only to tubes containing seminal plasma alone. Animal response was not different $(P>0.61)$ for treatments.

Large neutrophil-sperm aggregates were noticed when fresh serum was added to spermatozoa (Fig. 1a). Counts could not be made from the dense aggregates, thus preventing a respresentative scoring. Aggregate formation was greatly diminished with a reduced incubation time (Fig. 1b). Therefore, the reduced incubation time was adopted for all subsequent experiments. In samples 
Table 1. Sperm phagocytosis and bactericidal activity of bovine neutrophils incubated with serum and non-dialysed seminal plasma

\begin{tabular}{|c|c|c|c|c|c|c|c|}
\hline & \multicolumn{7}{|c|}{ Treatment } \\
\hline & 1 & 2 & 3 & 4 & 5 & 6 & $7^{*}$ \\
\hline Serum & + & + & - & - & - & - & - \\
\hline Heated serum & - & - & + & + & - & - & - \\
\hline Seminal plasma & - & + & - & + & + & - & + \\
\hline$\%$ Phagocytosis & $\begin{array}{c}24^{\mathrm{cd}} \\
(18-31)\end{array}$ & $\begin{array}{c}16^{\mathrm{c}} \\
(12-21)\end{array}$ & $\begin{array}{c}33^{\mathrm{d}} \\
(26-42)\end{array}$ & $\begin{array}{c}14^{\mathrm{bc}} \\
(10-18)\end{array}$ & $\begin{array}{c}5^{\mathrm{ab}} \\
(2-8)\end{array}$ & $\begin{array}{c}\mathbf{l}^{\mathbf{a}} \\
(0-3)\end{array}$ & ND \\
\hline$\%$ Dead bacteria & $\begin{array}{c}60^{\mathrm{a}} \\
(52-70)\end{array}$ & $\begin{array}{c}60^{\mathrm{a}} \\
(52-90)\end{array}$ & ND & ND & $\begin{array}{c}63^{\mathrm{a}} \\
(55-73)\end{array}$ & ND & $\begin{array}{c}68^{\mathrm{a}} \\
(59-79)\end{array}$ \\
\hline
\end{tabular}

ND, not done; -, test fluid was excluded from treatment; +, test fluid was included in treatment.

*Neutrophils omitted.

Values are reported as the geometric mean and $95 \%$ confidence interval in parentheses.

Means with no common superscript are different $(P<0.05)$.

having fresh or heated serum, some activated neutrophils were found shaped as a sperm head. Since a sperm head could not be identified within the neutrophil, these neutrophils could not be scored as phagocytic. When seminal plasma was added, neutrophil activity was reduced considerably (Fig. 1d). Most neutrophils had a round, non-activated appearance characteristic of buffer control cells. The addition of $10 \%$ seminal plasma did not completely prevent the activation of neutrophils associated with sperm cells (Fig. 1d), but the degree of activation was noticeably less than seruminduced activation (Fig. 1c).

Non-dialysed seminal plasma had inherent bactericidal activity (Table 1), masking any potential inhibition of neutrophil function. Subsequent experimentation showed that the bactericidal activity could be removed by dialysis.

\section{Experiment 2}

A dose-response of dialysed seminal plasma was measured using the sperm phagocytic assay (Table 2). All concentrations of seminal plasma decreased serum-dependent phagocytic activity $(P<0.01)$. When seminal plasma concentrations were increased to $50 \%$, serum-induced phagocytic activity was not different $(P>0.01)$ from the activity of neutrophils in seminal plasma or buffer alone. Treatment effects were not impaired by animal effects $(P>0.55)$. Because both fresh and heated serum initiated a phagocytic response to spermatozoa in Exp. 1, the association of immunoglobulins with spermatozoa was investigated (Griffin, 1982). Cytocentrifuge samplings of the assay tubes were stained to detect $\operatorname{IgG}_{1}, \operatorname{IgG}_{2}$ and $\mathrm{IgM}$. Spermatozoa incubated in serum alone were intensly stained for the 3 immunoglobulins. Increasing concentrations of seminal plasma appeared to remove the sperm-immunoglobulin association (Figs $2 \mathrm{a}, 2 \mathrm{~b}$ and $2 \mathrm{c}$, respectively). Interpretation was made difficult by peroxidase-reactive material coating the slide when seminal plasma was added to serum. Inherent peroxidase activity of the neutrophil indicated that differences in intensity of sperm cells were not due to reaction rate of the substrate. At some sites of neutrophil-sperm attachment, peroxidase activity was noticeably increased. It could not be determined whether this increased reactivity was due to the sperm cell or from cytoplasmic projections of the neutrophil.

\section{Experiment 3}

Phagocytosis of spermatozoa was not different $(P>0.01)$ after dialysis and heating when compared to non-dialysed seminal plasma and the PBS control (Table 3). After ether extraction, phagocytic activity increased but the activity was less than for serum alone $(P<0.01)$. 

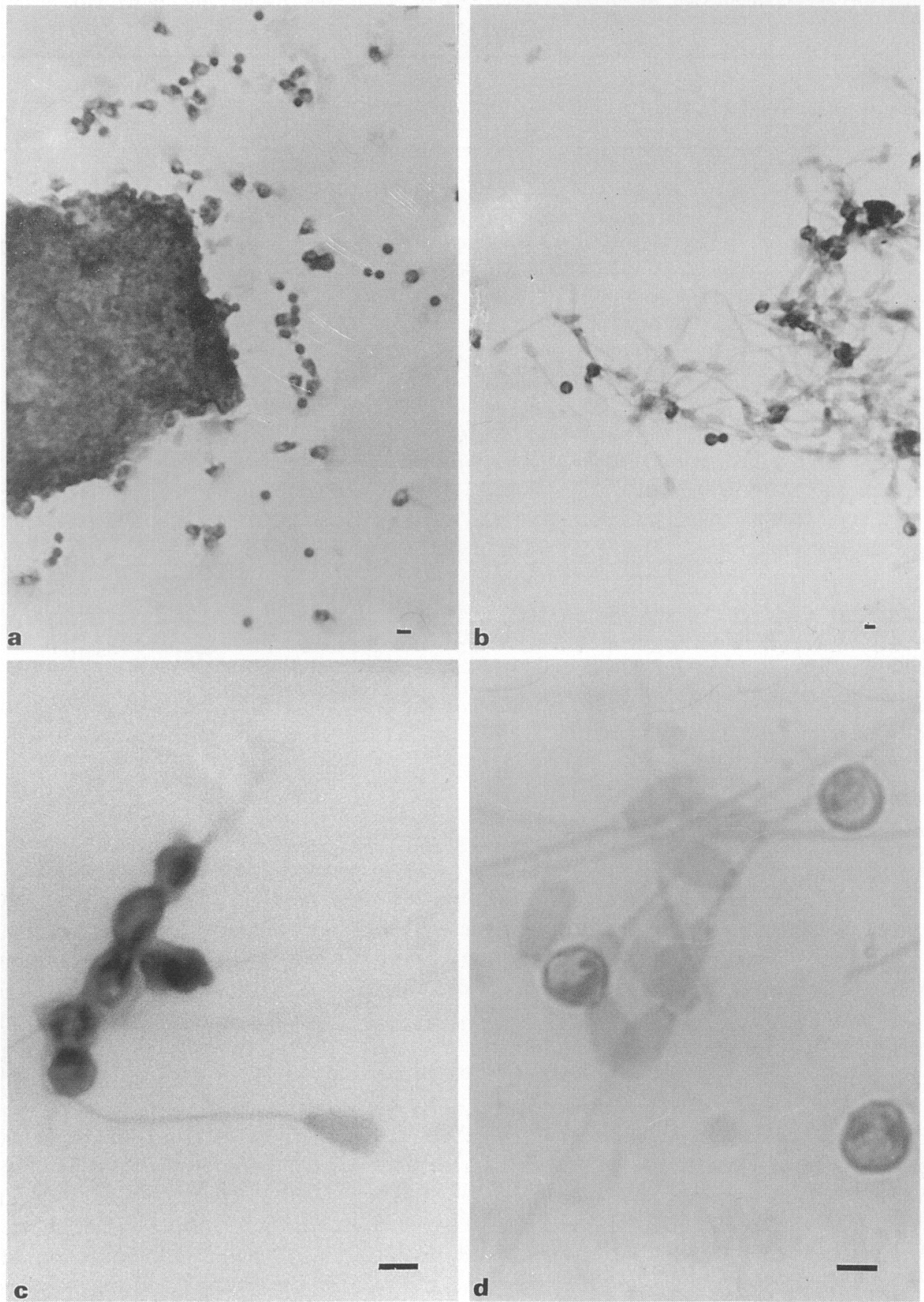

Fig. 1. Reactions of neutrophils and spermatozoa. (a) Large aggregate formation of neutrophils and sperm cells after $30 \mathrm{~min}$ of incubation at $37^{\circ} \mathrm{C}$. (b) Neutrophils are readily seen adhering to and phagocytosing spermatozoa after a 10-min incubation. (c) Phagocytosis was considered to have started when the cytoplasm of the neutrophil began to extend over the sperm cell. (d) When $10 \%$ seminal plasma was added, most cells retained a round, non-activated appearance. One neutrophil in contact with a sperm head has begun pseudopod formation. Cells were stained with Harris' haematoxylin and erythrosin B. Bar $=5 \mu \mathrm{m}$. 
Table 2. Effect of dialysed seminal plasma dose on serum-mediated sperm phagocytosis

\begin{tabular}{lcccccc}
\hline & \multicolumn{5}{c}{ Treatment } \\
\cline { 2 - 7 } & 1 & 2 & 3 & 4 & 5 & 6 \\
\hline Serum* $^{*}$ & 10 & 10 & 10 & 10 & None & None \\
Seminal plasma* & None & 10 & 25 & 50 & 10 & None \\
\% Phagocytosis & $40^{\mathrm{c}}$ & $23^{\mathrm{b}}$ & $20^{\mathrm{b}}$ & $5^{\mathrm{a}}$ & $9^{\mathrm{a}}$ & $4^{\mathrm{a}}$ \\
& $(31-50)$ & $(18-30)$ & $(15-26)$ & $(3-8)$ & $(6-13)$ & $(1-7)$ \\
\hline
\end{tabular}

*Percentage used for each treatment.

Values are reported as the geometric mean and $95 \%$ confidence interval in parentheses; $n=5$.

Means not sharing common superscript are different $(P<0 \cdot 01)$.

With the addition of serum, $45 \%(27-74 \%)$ (geometric mean and $(95 \%$ confidence interval)) of the bacteria were killed. Dialysed and ether-treated seminal plasma prevented serum-induced bactericidal activity. Colony forming units of $S$. aureus in dialysed and ether-extracted seminal plasma $\left(214 \times 10^{4} \pm 38 \times 10^{4}\right.$ and $234 \times 10^{4} \pm 47 \times 10^{4}$, respectively; mean \pm s.d. $)$ were reduced $(P<0.01)$ with the addition of serum to $154 \times 10^{4} \pm 41 \times 10^{4}$ and $170 \times 10^{4} \pm 52 \times 10^{4}$ colony-forming units, respectively). Examination of Giemsa-stained neutrophil smears revealed some neutrophils associated with a large number of bacteria. It could not be determined whether the bacteria were internalized or attached to the cell. Such activity was not evident when seminal plasma was added to neutrophils and bacteria. Viability of neutrophils selected from control and experimental tubes in both assays was $98 \%$ live compared to an initial Trypan blue determination of $96 \%$ live.

\section{Experiment 4}

Viability of neutrophils stored at $4{ }^{\circ} \mathrm{C}$ or of neutrophils rotated at $37^{\circ} \mathrm{C}$ in PBS or in $50 \%$ dialysed seminal plasma for $2 \mathrm{~h}$ was 98,99 and $97 \%$ live, respectively, and did not appear to change from an initial viability of $99 \%$ live. All cells inspected after the preincubation were uniform in shape with no signs of activation. Neutrophil bactericidal activity after the $2 \mathrm{~h}$ preincubation was $39 \%(30-48 \%), 46 \%(37-58 \%)$ and $36 \%(29-45 \%)$ dead (geometric mean and $(95 \%$ confidence interval)) and was not different for any of the three treatments $(P>0.01)$.

\section{Discussion}

This study has demonstrated the inhibition of bovine neutrophil phagocytosis by seminal plasma. Since neutrophils normally move to their 'prey' (Verhoef \& Waldvogel, 1985), movement may be mistaken for the early stages of phagocytosis (Griffin, 1982). Therefore, a bactericidal assay which has no extracellular killing activity can lend additional support for the determination of sperm phagocytosis. Before dialysis, seminal plasma was found to be bactericidal. Bactericidal activity may be due to seminalplasmin (Scheit \& Zimmer, 1984), a calcium-transport inhibitor (Lewis $e t$ al., 1985), or spermine cytotoxic oxidation products from amine oxidase activity of bovine serum (Allen \& Roberts, 1986). After dialysis, seminal plasma was not bactericidal and was not toxic to neutrophils incubated for $2 \mathrm{~h}$ in seminal plasma before assay or to neutrophils in the presence of serum. It is possible that spermine or its oxidation products may change neutrophil metabolism (Allen \& Roberts, 1986) without altering Trypan blue exclusion.

The chemiluminescent response of zymosan-challenged neutrophils and macrophages, an indicator of microbicidal activity, is inhibited by human seminal plasma (James et al., 1983; Schopf 


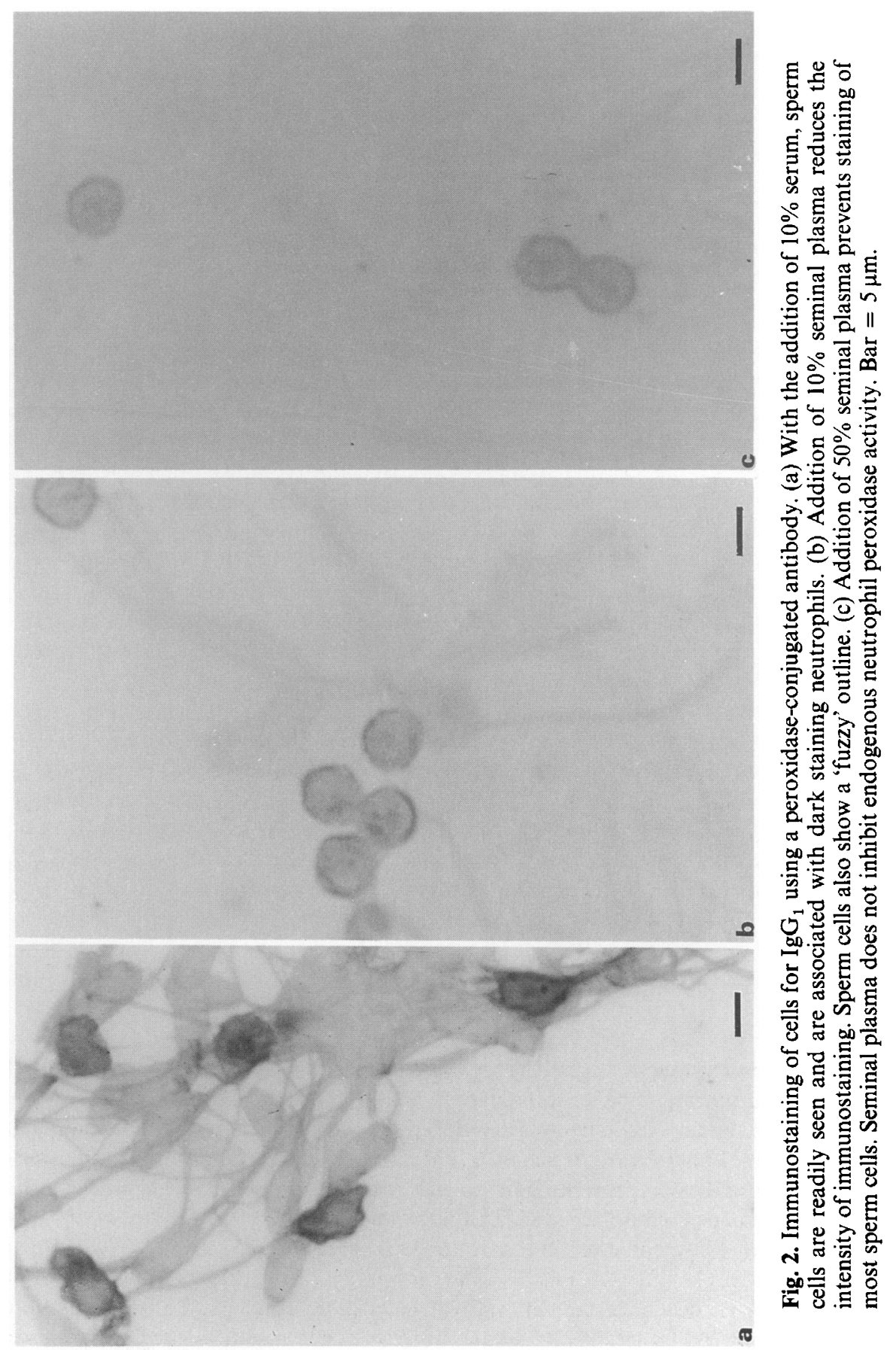


Table 3. Comparison of different treatments of pooled seminal plasma affecting bovine neutrophil sperm phagocytosis

\begin{tabular}{|c|c|c|c|c|c|c|c|c|c|c|}
\hline \multirow{4}{*}{$\begin{array}{l}\text { Seminal plasma } \\
\text { Serum }\end{array}$} & \multicolumn{10}{|c|}{ Treatment } \\
\hline & \multicolumn{2}{|c|}{ Non-dialysed } & \multicolumn{2}{|c|}{ Dialysed } & \multicolumn{2}{|c|}{ Heated } & \multicolumn{2}{|c|}{ Ether extracted } & \multicolumn{2}{|c|}{ Control } \\
\hline & + & + & + & + & + & + & + & + & - & - \\
\hline & - & + & - & + & - & + & - & + & - & + \\
\hline$\%$ Phagocytosis & $\begin{array}{r}1^{2} \\
(0-2)\end{array}$ & $\begin{array}{r}0^{\mathrm{a}} \\
(0-2)\end{array}$ & $\begin{array}{r}5^{a b} \\
(4-7)\end{array}$ & $\begin{array}{r}3^{a} \\
(2-5)\end{array}$ & $\begin{array}{r}5^{a} \\
(4-6)\end{array}$ & $\begin{array}{c}6^{\mathrm{ab}} \\
(4-8)\end{array}$ & $\begin{array}{c}14^{\mathrm{bc}} \\
(12-17)\end{array}$ & $\begin{array}{c}14^{\mathrm{bc}} \\
(12-17)\end{array}$ & $\begin{array}{c}0^{\mathrm{a}} \\
(0-1)\end{array}$ & $\begin{array}{c}33^{\mathrm{d}} \\
(27-37)\end{array}$ \\
\hline
\end{tabular}

+ , test fluid included in treatment; - , test fluid excluded from treatment.

Values are reported as the geometric mean and $95 \%$ confidence interval in parentheses.

Means not sharing the same superscript are different $(P<0 \cdot 01)$.

et al., 1984). Unlike the present study, the suppression was removed by dialysis, suggesting an inhibition by low molecular weight components (Schopf et al., 1984). The inhibitory activity in the present study, was heat-stable to $56^{\circ} \mathrm{C}$ but did not appear to be long lasting as neutrophil bactericidal activity was present after a 2-h preincubation with seminal plasma. Protein components in bovine seminal plasma suppress Concanavalin A-induced blastogenesis (Fahmi et al., 1985). An ether-extractable component of bovine seminal plasma was also immunosuppressive, suggestive of a prostaglandin effect (Fahmi et al., 1985). Although prostaglandins can also affect neutrophil function (Till et al., 1979), results from this study suggest that another component is also inhibitory because ether treatment reduced but did not remove the antiphagocytic activity.

The mechanism of inhibition is not clear. Proteases are present in seminal plasma (Polakoski \& Kopta, 1982). A protease, by altering neutrophil receptor activity, may be responsible for the inhibition. The inhibition would probably depend on constant exposure to seminal plasma since macrophages may recycle specific receptors (Molnar et al., 1987). A protein in human seminal plasma can complex immunoglobulin G (Witkin et al., 1983). Reduced staining for immunoglobulins on sperm cells in the presence of seminal plasma as seen in this study suggests a similar activity in the bull. It should be noted though that serum is not a normal component of the reproductive tract. Therefore, a definition of phagocytic requirements for spermatozoa is needed before it can be determined whether this activity will inhibit phagocyte function. Seminal plasma may also coat the sperm cell, reducing recognition. A sperm-coating antigen from the seminal vesicle of men and rabbits has been postulated to reduce sperm antigenicity by binding tightly to the cell surface (Weil \& Stefanovic, 1969). If a coating mechanism occurs in the bull, the ligand does not appear to bind tightly because washed spermatozoa were readily ingested by neutrophils in the presence of serum.

A major difficulty in the interpretation of sperm phagocytosis was the formation of large neutrophil aggregates and sperm agglutination when serum was used alone. Heating serum $\left(56^{\circ} \mathrm{C}\right.$ for $30 \mathrm{~min}$ ) improved scoring, indicating that sperm ingestion is not dependent on complement. A decreased incubation time in fresh serum also reduced aggregate formation allowing interpretation and mimicry of in-vivo conditions more closely. The assay should be helpful in determining events needed for the sperm-phagocyte interaction. An advantage of the present system is the scoring of neutrophils ingesting one of a number of agglutinated spermatozoa. Use of a neutrophil monolayer system (Raynor et al., 1981) could easily lead to overestimates of phagocytosis if agglutination is considerable.

Spermatozoa are readily ingested by vaginal leucocytes (Phillips \& Mahler, 1977a) and epithelial cells (Phillips \& Mahler, 1977b). An antiphagocytic action of seminal plasma would be beneficial to sperm survival in the female genital tract. Isolation of the inhibitory component(s) may be of particular value to the artificial insemination industry in providing increased sperm survival and/or in allowing a larger number of inseminations from an ejaculate. 
I thank J. Floyd Wiedler and C. H. Allen of Atlantic Breeders Service for help. This work was supported in part by USDA 1433 Formula Funds.

\section{References}

Alexander, N.J. \& Anderson, D.J. (1987) Immunology of semen. Fert. Steril. 47, 192-205.

Allen, R.D. \& Roberts, T.K. (1986) The relationship between the immunosuppressive and cytotoxic effects of human seminal plasma. Am. J. Reprod. Immunol. Microbiol. 11, 5964.

Austin, C.R. (1957) Fate of spermatozoa in the uterus of the mouse and rat. J. Endocr. 14, 335-342.

Bedford, J.M. (1965) Effect of environment on phagocytosis of rabbit spermatozoa. J. Reprod. Fert. 9, 249-256.

Bedford, J.M. \& Witkin, S.S. (1983) Influence of complement depletion on sperm function in the female rabbit. J. Reprod. Fert. 69, 523-528.

Bergroth, V., Reitamo, S., Konttinen, Y.T. \& Lalla, M. (1980) Sensitivity and nonspecific staining of various immunoperoxidase techniques. Histochemistry $\mathbf{6 8}$, 17-22.

Blandau, R.J. \& Odor, D.L. (1949) The total number of spermatozoa reaching various segments of the reproductive tract in the female albino rat at intervals after insemination. Anat. Rec. 103, 93-110.

Busolo, F., Zanchetta, R., Lanzone, E \& Cusinato, K. (1984) Microbial flora in semen of asymptomatic infertile men. Andrologia 16, 269-275.

Fahmi, H.A., Hunter, A.G., Markham, R.J.F. \& Seguin, B.E. (1985) Identification of an immunosuppressive protein in bovine seminal plasma with activity against bovine lymphocytes. J. Dairy Sci. 68, 23222328.

Friberg, J. \& Fullan, N. (1983) Attachment of Escherichia coli to human spermatozoa. Am. J. Obstet, Gynecol. 146, 465-467.

Fowler, J.E. \& Mariano, M. (1984) Difficulties in quantitating the contribution of urethral bacteria to prostatic fluid and seminal fluid cultures. J. Urol. 132, 471-473.

Griffin, F.M., Jr (1982) Mononuclear cell phagocytic mechanisms and host defense. In Advances in Host Defense Mechanisms, Vol. 1, pp. 31-55. Eds J. I. Gallin \& A. S. Fauci. Raven Press, New York.

Hawk, H.W., Turner, G.D. \& Sykes, J.F. (1960) The bactericidal properties of uteri and uterine exudates of rabbits with reduced leukocyte activity. Am.J. vet. Res. 21, 657-663.

Hoffman, T.A. \& Bullock, W.E. (1973) A statistical approach to the polymorphonuclear leukocyte bactericidal assay. J. Lab. Clin. Med. 81, 148-156.

Howe, G.R. \& Black, D.L. (1963) Spermatozoan transport and leucocytic responses in the reproductive tract of calves. J. Reprod. Fert. 6, 305-311.

Hurn, B.A.L. \& Chantler, S.M. (1980) Production of reagent antibodies. In Methods of Enzymology, Vol. 70, pp. 104-142. Eds H. Van Vunakis \& J. L. Langone. Academic Press, New York.

James, K., Bradbury, A.W., Hargreave, T.B. \& Cullen, R.T. (1983) The effect of seminal plasma on macro- phage function-A possible contributory factor in sexually transmitted disease. Aids Res. 1, 45-57.

Lewis, R.V., San Agustin, J., Kruggel, W. \& Lardy, H.A. (1985) The structure of caltrin, the calcium-transport inhibitor of bovine seminal plasma. Proc. natn. Acad. Sci. USA 82, 6490-6491.

Marcus, S.L. (1966) Influence of ovarian hormones on the leukocytic response to spermatozoa in the uterus of the golden hamster. Fert. Steril. 17, 212-220.

Matousek, J. (1985) Biological and immunological roles of proteins in the sperm of domestic animals (review). Anim. Reprod. Sci. 8, 1-40.

Menge, A.C., Tyler, W.J. \& Casida, L.E. (1962) Factors affecting the removal of spermatozoa from the rabbit uterus. J. Reprod. Fert. 3, 396- 404.

Molnar, J., Hoekstra, S., Ku, C. S-L. \& Van Alten, P. (1987) Evidence for the recycling nature of the fibronectin receptor or macrophages. J. cell. Physiol. 131, 374-383.

Olive, D.L., Weinberg, J.B. \& Haney, A.F. (1987) Spermmacrophage interaction in the mouse: a quantitative assay in vitro using indium oxine-labeled sperm. Biol. Reprod. 37, 1170-1178.

Parr, E.L. \& Parr, M.B. (1985) Secretory immunoglobulin binding to bacteria in the mouse uterus after mating. J. Reprod. Immunol. 8, 71-82.

Parr, E.L., Schaedler, R.W. \& Hirsch, J.G. (1967) The relationship of polymorphonuclear leukocytes to infertility in uteri containing foreign bodies. J. exp. Med. 126, 523-537.

Phillips, D.M. \& Mahler, S. (1977a) Leukocyte emigration and migration in the vagina following mating. Anat. Rec. 189, 45-60.

Phillips, D.M. \& Mahler, S. (1977b) Phagocytosis of spermatozoa by the rabbit vagina. Anat. Rec. 189, $61-72$.

Polakoski, K.L. \& Kopta, M. (1982) Seminal plasma. In Biochemistry of Mammalian Reproduction, Vol. 1, pp. 89-117. Eds L. J. D. Zaneveld \& R. T. Chatterton. John Wiley and Sons, New York.

Raynor, R.H., Doran, J.E. \& Reese, A.C. (1981) A polymorphonuclear leukocyte monolayer system for studies of phagocytosis. J. Reticuloendoth, Soc. 29 , 441-449.

Scheit, K.H. \& Zimmer, M. (1984) Seminal plasmin, an antimicrobial protein from bull semen, inhibits gene expression in E. coli. Biochim. Biophys. Acta 781, 187-191.

Schopf, R.E., Schramm, P., Benes, P. \& Morsches, B. (1984) Seminal plasma-induced suppression of the respiratory burst of polymorphonuclear leukocytes and monocytes. Andrologia 16, 124-128.

Sokal, R.R. \& Rohlf, F.J. (1981) Biometry. W. H. Freeman \& Co., San Francisco.

Strzemienski, P.J., Dyer, R.M., Sertich, P.L., Garcia, M.C. \& Kenney, R.M. (1987) Bactericidal activity of 
peripheral blood neutrophils during the oestrous cycle and early pregnancy in the mare. J. Reprod, Fert. 80, 289-293.

Till, G., Kownatzki, E., Seitz, M. \& Gemsa, D. (1979) Chemokinetic and chemotactic activity of various prostaglandins for neutrophil granulocytes. Clin. Immunol. Immunopathol. 12, 111-118.

Verhoef, J. \& Waldvogel, F.A. (1985) Testing phagocytic cell function. Eur. J. clin. Mircrobiol. 4, 379-391.
Weil, A.J. \& Stefanovic, D. (1969) Spermatozoa-coating antigen (SCA): its persistence in the genital tract of female rabbits. Fert. Steril. 20, 689-692.

Witkin, S.S., Richards, J.M., Bongiovanni, A.M. \& Zelikovsky, G. (1983) An IgG-Fc binding protein in seminal fluid. Am. J. Reprod, Immunol. 3, 23-27.

Received 14 February 1989 